\title{
Od edukacji spersonalizowanej do edukacji społecznej, czyli od pasji naukowej do studenckich projektów dotyczących nowotworów złośliwych
}

\author{
Katarzyna Morańska ${ }^{1}$, Maria Gwit ${ }^{1}$ Agnieszka Knopik-Skrocka² \\ Uniwersytet im. Adama Mickiewicza w Poznaniu, \\ ${ }^{7}$ Wydział Biologii, Sekcja Medycyny Regeneracyjnej i Badań nad Nowotworami Koła Naukowego Przyrodników \\ ${ }^{2}$ Wydział Biologii, Zakład Biologii Komórki, Sekcja Medycyny Regeneracyjnej i Badań nad Nowotworami \\ Koła Naukowego Przyrodników \\ E-mail:katarzyna.moranska@outlook.com,maria.gwit20@gmail.com,askro@amu.edu.pl
}

Stowa kluczowe: edukacja spersonalizowana, tutoring, edukacja społeczna, projekt, nowotwory

\section{Od słów do działania}

Od kilku lat na Wydziale Biologii UAM w Poznaniu realizowana jest idea tzw. edukacji spersonalizowanej w formie tutoringu. Tutoring stwarza niezwykłą możliwość spotkania w relacji uczeń-nauczyciel (tutee-tutor). Tutor dzieli się swoją wiedzą, doświadczeniem, zadaje pytania, pomaga znaleźć na nie odpowiedzi, dąży do rozwoju swojego podopiecznego. Szczególnie ważną cechą tutora jest to, aby chciał słuchać swojego rozmówcy, nie narzucając gotowych rozwiązań, lecz zachęcając studenta do samodzielnych poszukiwań, przemyśleń. Bardzo pomocne w takiej pracy są narzędzia z zakresu twórczego myślenia, jak mapa myśli, czy Scamper, a także przygotowanie przez tutee posteru konferencyjnego. Równie ważna w tutoringu jest dobra atmosfera panująca mię- dzy tutee i tutorem, wzajemne zaufanie, autentyczność. Dzięki temu wszystkiemu tutoring staje się przestrzenią, w której może rozwinąć się pasja i kreatywność studenta.

Jednym z obszarów tematycznych jakiemu są poświęcone tutoriale prowadzone przez dr Agnieszkę Knopik-Skrocką, prof. UAM jest biologia nowotworów, ich diagnostyka i terapia. Ważnym efektem spotkań tutee z tutorem są zarówno eseje, artykuły naukowe (Krakowiak, Knopik-Skrocka, 2018); (Modrzyński i in., 2019a), jak i wykłady prowadzone przez tutee podczas Nocy Biologów, Festiwalu Nauki, czy wreszcie udział w konferencji (Modrzyński i in., 2019b). Wiedza oraz doświadczenie zdobyte w tym czasie przyczyniły się do podjęcia przez niektórych z nich decyzji o zostaniu członkiem studenckiej Sekcji Medycyny Regeneracyjnej i Badań nad Nowotworami.

Sekcja kierowana przez Katarzynę Morańską zrzesza studentów będących pasjonatami tematyki związanej z nowotworami. Nowotwory złośliwe zajmują centralną 
pozycję, wokół której działa sekcja. Studentów interesują zagadnienia zarówno z zakresu etiologii nowotworów, epidemiologii, genetyki, immunologii oraz odpowiedzi na terapię. Mutacje genetyczne i zmiany epigenetyczne komórek nowotworowych, jak również te zachodzące w obrębie ich mikrośrodowiska, odpowiadają za heterogenność nowotworów (Prasetyanti i Medema, 2017); (Knopik-Skrocka i in., 2017); (Dagogo-Jack i in., 2018). Dzięki nawiązaniu współpracy z firmą biotechnologiczną genXone udało się zorganizować warsztaty (online), podczas których studenci mogli poznać założenia metod stosowanych do wykrywania mutacji w komórkach. Podczas spotkań, członkowie sekcji dzielą się nowościami naukowymi, ale także różnymi pomysłami na wykorzystanie tej wiedzy. Aby takie pomysły zaistniały potrzebna jest, podobnie jak w edukacji spersonalizowanej, przyjazna atmosfera, zaufanie, otwartość i odpowiedzialność. Edukacja nastawiona na takie wartości jest także możliwa w grupie, czego przykładem jest nasza sekcja.

Parafrazując tzw. złoty krąg Simona Sinka, można powiedzieć, iż to dzięki częstemu zadawaniu sobie pytań co?, jak?, dlaczego?, dzięki wspólnej pasji, zaangażowaniu, wzajemnemu inspirowaniu i wreszcie chęci podzielenia się wiedzą z innymi, zrodziły się projekty dotyczące nowotworów złośliwych (Ryc. 1). Przyświecał im nadrzędny cel - zwrócenie uwagi społeczeństwa na znaczenie profilaktyki nowotworów złośliwych oraz wczesnej diagnostyki dla strategii terapeutycznych. W taki oto sposób członkowie sekcji podjęli się ważnego i odpowiedzialnego działania, tj. edukacji społecznej, rozumianej jako praca skierowana na poszerzanie wiedzy, umiejętności z danego obszaru tematycznego. O tym jak powstały i zostały zrealizowane "PIERwSI W DŁOŃ oraz "Skarby w dłoń" chcemy podzielić się w dalszej części pracy.
Sympozja „PIERwSI W DŁON”” (20192020)

Podjęta przez nas inicjatywa "PIERwSI W DŁOŃ" skupiła się, jak sama nazwa wskazuje, wokół raka piersi. Jest to bowiem najczęściej wykrywany nowotwór na świecie (https://gco.iarc.fr/today/home). W Polsce, co roku diagnozowanych jest prawie 20 tysięcy nowotworów piersi u kobiet (http://onkologia.org.pl/wp-content/uploads/Nowotwory 2017.pdf). Niepokojący jest także ogólnoświatowy trend, zgodnie z którym coraz więcej jest przypadków raka piersi u młodych kobiet (<40 roku życia) (Anastasiadi i in., 2017). Pomysł na projekt zrodził się z chęci rozpowszechnienia wśród kobiet instruktażu samobadania piersi. Prawidłowo przeprowadzone badanie to niezwykle ważny element profilaktyki. Dzięki niemu możliwe jest wychwycenie zmian i szybka reakcja na nie. We współpracy z Uniwersyteckim Stowarzyszeniem Onkologii Multidyscyplinarnej przy Uniwersytecie Medycznym w Poznaniu, zorganizowane zostało w marcu 2019 roku I Sympozjum, nad którym patronat medialny objęło Stowarzyszenie Boost Biotech Polska. Wśród zaproszonych prelegentów była m.in. dr hab. Hanna Dams-Kozłowska z Pracowni Immunologii Nowotworów z Wielkopolskiego Centrum Onkologii (WCO) z wykładem pt. "Sfery bioinżynierowanego jedwabiu jako nośnik leków w terapii nowotworów”. Wykład pt: „ABC raka piersi współczesne spojrzenie na diagnostykę i terapię" wygłosiła Monika Pieniawska, studentka Wydziału Biologii UAM i ówczesna Kierownik sekcji. Poza wykładami, przeprowadzono warsztaty, które były kontynuowane w ciągu kolejnych miesięcy podczas festiwali popularnonaukowych. 


\section{Tutoring Gedanensis}

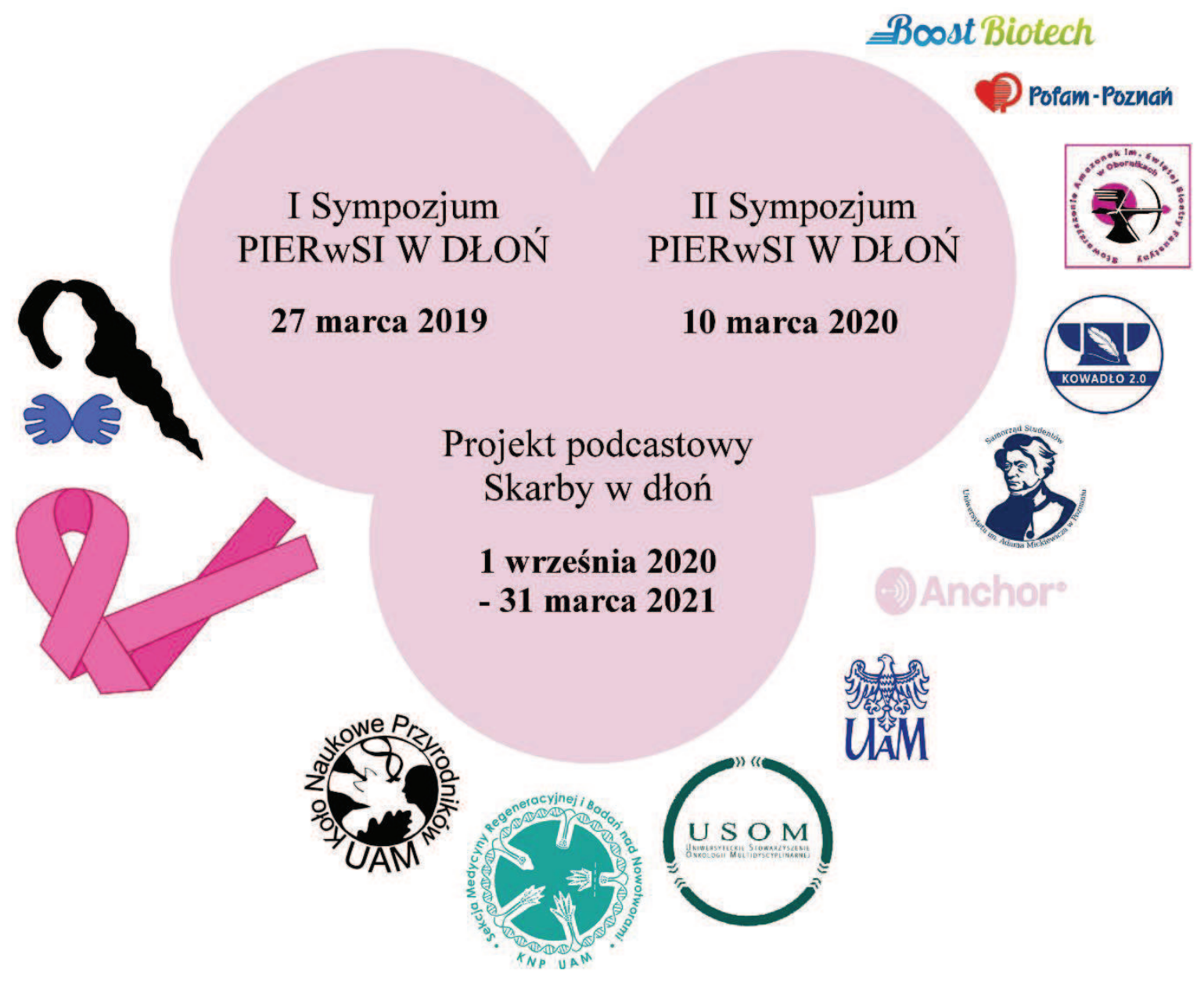

Ryc.1. Projekty studenckie Sekcji Medycyny Regeneracyjnej i Badań nad Nowotworami Koła Naukowego Przyrodników UAM w zakresie profilaktyki nowotworów oraz zwiększenia świadomości o znaczeniu wczesnej diagnostyki dla skutecznego leczenia

Bazując na zdobytym doświadczeniu, w roku 2020 sekcja zorganizowała II Sympozjum, tym razem z szerzej zakrojoną akcją promocyjną (https://www.youtube.com/watch?v=dtmsACeLWPci) i patronatem JM Rektora UAM. Część merytoryczna sympozjum obejmowała m. in. wykład chirurga lek. med. Konrada Listwana z Wielkopolskiego Centrum Onkologii pt. „Rak piersi u młodych kobiet spojrzeniem chirurga onkologa", a także spotkanie z dr n. med. Maciejem Dąbrowskim, przedstawicielem firmy MNM Diagnostics Poznań Sp. z 0.O., który opowiedział o profilowaniu całogenomowym w potrójnie ujemnym raku piersi.
Podobnie jak podczas I Sympozjum, zorganizowano warsztaty $\mathrm{z}$ samobadania piersi, z wykorzystaniem fantomów zakupionych przy wsparciu Dziekana WB UAM. W warsztatach wzięły udział także przedstawicielki Stowarzyszenia Amazonki im. św. Siostry Faustyny z Obornik oraz studenci Fizjoterapii z Uniwersytetu Medycznego im. Karola Marcinkowskiego w Poznaniu. Dzięki powyższym działaniom uczestnicy sympozjum mogli uzyskać wiele cennych porad i praktycznych wskazań na temat swojego zdrowia i profilaktyki nowotworów. 
Bardzo ważnym punktem wydarzenia w naszym odczuciu była dyskusja panelowa z udziałem dr n. med. Dariusza Godlewskiego, Kierownika Ośrodka Profilaktyki i Epidemiologii Nowotworów w Poznaniu (OPEN) oraz kobiet, które zechciały podzielić się historią swojej choroby. Wśród nich była Pani dr hab. Bożena Sikora, Prof. UAM, osoba bardzo zaangażowana w projekty naszej sekcji. Wspomniana dyskusja i udział publiczności udowodniły jak ważna i potrzebna jest przestrzeń do rozmowy. W ten sposób, mówiąc językiem medycznym, zdiagnozowana została potrzeba połączenia głosu pacjentów z głosem specjalistów. Równocześnie zauważono, iż o ile temat raka piersi jest często poruszany w przestrzeni publicznej, to wciąż tematem tabu jest rak jądra, czy prostaty. I tak zrodził się pomysł na "Skarby w dłoń".

\section{Projekt podcastowy „Skarby w dłoń” (2020-2021)}

To projekt, inny niż wcześniejsze, mający formę wywiadów podcastowych, nagranych jako cykl rozmów z zaproszonymi lekarzami, naukowcami, psychologami, a także pacjentami. Od strony merytorycznej został multidyscyplinarnie poszerzony o tematy związane z nowotworami jąder i prostaty. W Polsce, rak jądra zajmuje niechlubne pierwsze miejsce wśród nowotworów mężczyzn w grupie wiekowej 10-44, osiągając ponad tysiąc nowych przypadków w roku 2020 (https://gco.iarc.fr/today/home). Z kolei grupa wiekowa mężczyzn 65+ zdominowana jest przez raka prostaty, który stanowi niemal 22\% zachorowań na nowotwory złośliwe w Polsce w wyżej wymienionej grupie wiekowej. Dodatkowo, w porównaniu z poprzednimi latami (http://onkologia.org.pl/wpcontent/uploads/Nowotwory 2017.pdf), coraz więcej odnotowuje się przypadków raka prostaty u młodszych mężczyzn. Bardzo nam zależało także na tym, aby projekt poszerzyć o zagadnienia z obszaru psychoonkologii, niezwykle ważnej i pomocnej dla pacjenta zarówno w czasie diagnostyki, jak i terapii.

Łącznie w przeciągu kilku miesięcy (wrzesień 2020 - marzec 2021) przeprowadzono 10 wywiadów. Swoistym sukcesem tego projektu jest różnorodność gości, którzy odwiedzili studio nagraniowe, choć było i tak, że studio jechało do specjalistów. Przykładem jest wywiad przeprowadzony w Gdańsku z dr n. med. Danielem Maliszewskim (chirurg piersi) i jego byłą pacjentką, współzałożycielką i prowadzącą Fundację Omea Life - Panią Eweliną Puszkin. Pierwszym wywiadem był jednak wywiad z dr n. med. Dariuszem Godlewskim, kierownikiem OPENu, który jak wspomniano wcześniej, rozpoczął z nami współpracę już przy projekcie "PIERwSI W DŁOŃ". Podczas wywiadu poruszono sytuację pacjentów onkologicznych w Polsce, możliwości i ograniczenia systemu służby zdrowia. Jest to rozmowa przydatna dla każdego, bez względu na to, w jakim stopniu nowotwory go dotyczą i ile na ich temat wie. To klamra kompozycyjna, od której warto rozpocząć słuchanie "Skarbów w dłoń" i do której warto wracać.

W gronie zaproszonych do wywiadów gości znaleźli się także m.in. dr n. med. radiolog Krzysztof Koziełek, lek. med. urolog Łukasz Wojnar, dr n. med. onkolog Joanna Kufel-Grabowska, psycholog dr Justyna Pach-Kołecka. Rozmowy nakierowano na konkretną wiedzę z zakresu diagnostyki, aktualnego leczenia nowotworów, nowych strategii terapeutycznych, jak również na rolę wsparcia psychologicznego podczas całego procesu leczenia oraz na codzienność życia z rakiem z perspektywy pacjenta.

Wywiady zostały zrealizowane w formule spotkań indywidualnych, z wykorzystaniem profesjonalnego sprzętu do nagrywania. Jego zakup został sfinansowany ze środków konkursu budżetowego Kowadło 2.0, organizowanego przez Parlament Samo- 
rządu Studentów UAM. Wszystkie wywiady są dostępne na stronie https://anchor.fm/skarbywdlon oraz na platformach, na których serwis Anchor prowadzi dystrybucję (Spotify, Breaker, Google Podcasts, Overcast, Pocket Casts oraz Radio Public). Członkowie sekcji podczas półrocznej pracy stworzyli holistyczny audioporadnik profilaktyki i diagnostyki, przekazując głosem gości merytoryczną wiedzę oraz ich doświadczenie.

\section{Podsumowanie i perspektywy}

Nadrzędnym celem uniwersytetu jest zapoznanie studentów z aktualną wiedzą i praktyką w studiowanej dziedzinie. Założeniem takiego kształcenia jest, aby młodzi ludzie zostali przygotowani w możliwie najlepszy sposób do przyszłej pracy zawodowej i funkcjonowania w społeczeństwie. Czas studiów powinien być czasem kreatywności i zdobywania doświadczeń. Niezwykłym atutem Uniwersytetu im. Adama Mickiewicza w Poznaniu jest udostępnianie studentom przestrzeni do rozwijania pasji w ramach tutoringu oraz realizacji pomysłów jakie rodzą się w grupie studenckiej. W tym ostatnim przypadku bardzo pomocne jest przekazywanie funduszy, udzielanie patronatów, miejsca dla organizowanych inicjatyw. Młodzi ludzie wspierani przez uczelnię, opiekunów naukowych są gotowi wyjść ze swoją wiedzą do społeczeństwa.

Realizacja przedstawionych w pracy projektów dała poczucie sprawczości i wpływu na rzeczywistość. Pasję naukową i młodzieńczy entuzjazm przekuto w pełnowymiarowe wydarzenia. Jednak to przede wszystkim odpowiedzialna współpraca, wzajemny szacunek i wytrwałe dążenie do celu odpowiadają za powodzenie działań. Studenci zdobyli doświadczenie zarówno jako jednostki, jak i grupa. Kształtowali umiejętności miękkie, tak ważne w pracy z drugim człowiekiem i udowodnili, że warto od siebie wymagać. Z perspektywy nauczyciela akademickiego, tutora, opiekuna sekcji, zespół młodych ludzi zbudował wspaniałą bazę do dalszego rozwoju i podejmowania odważnych działań w przyszłości.

Powstałe projekty to wynik pracy, wsparcia i zaangażowania wielu osób (Tab.1). Opisane inicjatywy stały się "kroplą drążącą skałę". Najlepszym orężem w walce z nowotworami jest bowiem wiedza, dzięki której zwiększa się świadomość o znaczeniu profilaktyki i wczesnej diagnostyki. Zainteresowanie z jakim spotkały się nasze działania pokazało jak wielka jest potrzeba umiejętnego łączenia nauki z edukacją. Sekcja stara się być w ciągłym kontakcie z osobami zainteresowanymi tematyką, prowadząc kanały na portalach społecznościowych - Instagramie i Facebook. Organizowane są także rozmowy live, podczas których można się bezpośrednio kontaktować z członkami sekcji. Przed wywiadami w ramach "Skarbów w dłoń" dodatkowo przygotowana została ankieta, dzięki której zebrano wiele pytań do gości. Zależało nam na tym, aby podcasty odpowiadały na realne problemy, wątpliwości i aby wniosły konkretną wiedzę w przystępny sposób. Jesteśmy przekonane, że warto to robić i równocześnie mamy nadzieję na kolejne wspólne inicjatywy.

\section{Podziękowania}

Autorki pragną podziękować wszystkim, którzy podjęli wyzwanie i pomogli w organizacji oraz realizacji przedsięwzięć. Szczególne podziękowania składamy Pani dr hab. Bożenie Sikorze, Prof. UAM oraz Pani mgr Monice Pieniawskiej za pomoc merytoryczną, marketingową i organizacyjną. 


\section{Tutoring Gedanensis}

Tab. 1. Lista twórców i gości wydarzeń projektowych (źródło: autorskie)

\begin{tabular}{|c|c|}
\hline Imię i nazwisko & Organizacja \\
\hline \multicolumn{2}{|c|}{ Bazowy sztab organizacyjny } \\
\hline Katarzyna Morańska & KNP, UAM, USOM, WCO \\
\hline Monika Pieniawska & KNP, UAM, USOM, WCO \\
\hline prof. UAM dr hab. Bożena Sikora & UAM \\
\hline prof. UAM dr Agnieszka Knopik-Skrocka & UAM \\
\hline Krzysztof Żyłka & USOM \\
\hline Aleksandra Pryczek & USOM \\
\hline \multicolumn{2}{|c|}{ I Sympozjum } \\
\hline \multicolumn{2}{|c|}{ Organizacja } \\
\hline Katarzyna Morańska & KNP, UAM, USOM, WCO \\
\hline Monika Pieniawska & KNP, UAM, USOM, WCO \\
\hline Krzysztof Żyłka & USOM \\
\hline Aleksandra Pryczek & USOM \\
\hline \multicolumn{2}{|l|}{ Wykłady } \\
\hline Monika Pieniawska & KNP, UAM, USOM, WCO \\
\hline prof. UAM dr Agnieszka Knopik-Skrocka & UAM \\
\hline Maria Gwit & KNP, UAM \\
\hline Tomasz Modrzyński & UAM \\
\hline dr hab. n. med. Hanna Dams-Kozłowska & WCO \\
\hline \multicolumn{2}{|c|}{ Warsztaty } \\
\hline Katarzyna Morańska & KNP, UAM, USOM, WCO \\
\hline Klara Dubisz & UM \\
\hline Blanka Borowiec & UAM \\
\hline \multicolumn{2}{|c|}{ Pomoc marketingowo-promocyjna } \\
\hline Mikołaj Rogula & Boost Biotech Polska \\
\hline \multicolumn{2}{|c|}{ Projekt podcastowy } \\
\hline \multicolumn{2}{|l|}{ Zespół } \\
\hline Katarzyna Morańska & KNP, UAM, USOM, WCO \\
\hline Joanna Budzik & KNP, UAM \\
\hline Oliwia Mazur & KNP, UAM \\
\hline Rut Bryl & KNP, UAM \\
\hline Oskar Kołacki & KNP, UAM \\
\hline Maria Gwit & KNP, UAM \\
\hline
\end{tabular}

\begin{tabular}{|c|c|}
\hline \multicolumn{2}{|c|}{ Wsparcie } \\
\hline prof. UAM dr hab. Bożena Sikora & UAM \\
\hline prof. UAM dr Agnieszka Knopik-Skrocka & UAM \\
\hline Krzysztof Żyłka & USOM \\
\hline Damien White & Medbay \\
\hline Michał Król & Politechnika Poznańska \\
\hline Julia Pietruszka & Grafik \\
\hline mgr Agnieszka Kurek-Hęś & UAM \\
\hline Daria Kamrowska & UAM \\
\hline \multicolumn{2}{|l|}{ Goście } \\
\hline dr n. med. Dariusz Godlewski & OPEN \\
\hline dr n. med. Krzysztof Koziełek & OPEN \\
\hline dr n. med. Daniel Maliszewski & $\begin{array}{l}\text { Praktyka lekarska- chirurg } \\
\text { piersi, Gdańsk }\end{array}$ \\
\hline Ewelina Puszkin & $\begin{array}{l}\text { Fundacja OmeaLife. Rak piersi } \\
\text { nie ogranicza }\end{array}$ \\
\hline lek. med. Łukasz Wojnar & $\begin{array}{l}\text { Praktyka lekarska - urolog, } \\
\text { Poznań }\end{array}$ \\
\hline dr Justyna Pach-Kołecka & $\begin{array}{l}\text { Praktyka - psycholog, } \\
\text { psychoterapeuta Poznań }\end{array}$ \\
\hline dr Joanna Kufel-Grabowska & WCO \\
\hline prof. UAM dr Agnieszka Knopik-Skrocka & UAM \\
\hline prof. UAM dr hab. Bożena Sikora & UAM \\
\hline
\end{tabular}

\begin{tabular}{ll}
\hline Imię i nazwisko & Organizacja \\
\hline & Bazowy sztab warsztatowy \\
\hline Katarzyna Morańska & KNP, UAM, USOM, WCO \\
\hline Klara Dubisz & UM \\
\hline Blanka Borowiec & KNP, UAM \\
\hline Marta Przymuszała & KNP, UAM \\
\hline Maria Gwit & KNP, UAM \\
\hline Sandra Pawlak & KNP, UAM \\
\hline Aleksandra Grzesik & KNP, UAM \\
\hline Kaja Jaskot & KNP, UAM \\
\hline Rut Bryl & KNP, UAM \\
\hline Emilia Korczmar & KNP, UAM \\
\hline Martyna Lewandowska & KNP, UAM \\
\hline Oliwia Mazur & KNP, UAM \\
\hline
\end{tabular}

\begin{tabular}{|c|c|}
\hline \multicolumn{2}{|c|}{ II Sympozjum } \\
\hline \multicolumn{2}{|c|}{ Organizacja } \\
\hline Katarzyna Morańska & KNP, UAM, USOM, WCO \\
\hline Monika Pieniawska & KNP, UAM, USOM, WCO \\
\hline prof. UAM dr hab. Bożena Sikora & UAM \\
\hline prof. UAM dr Agnieszka Knopik-Skrocka & UAM \\
\hline Krzysztof Żyłka & USOM \\
\hline
\end{tabular}

\begin{tabular}{ll}
\multicolumn{2}{c}{ Wykłady } \\
\hline lek. med. Konrad Listwan & WCO \\
\hline dr n. med. Maciej Dąbrowski & MNM Diagnostics Sp. z o. o. \\
\hline dr n. med. Dariusz Godlewski & OPEN \\
prof. UAM dr Agnieszka Knopik-Skrocka & UAM \\
Monika Pieniawska & KNP, UAM, USOM, WCO
\end{tabular}

\begin{tabular}{ll}
\hline \multicolumn{1}{c}{ Warsztaty } \\
\hline Katarzyna Morańska & KNP, UAM, USOM, WCO \\
\hline Marta Przymuszała & KNP, UAM \\
\hline Maria Gwit & KNP, UAM \\
\hline Sandra Pawlak & KNP, UAM \\
\hline Aleksandra Grzesik & KNP, UAM \\
\hline Kaja Jaskot & KNP, UAM \\
\hline Rut Bryl & KNP, UAM \\
\hline Emilia Korczmar & KNP, UAM \\
\hline Martyna Lewandowska & KNP, UAM \\
\hline Oliwia Mazur & KNP, UAM \\
\hline
\end{tabular}

\begin{tabular}{ll}
\multicolumn{2}{c}{ Stanowiska } \\
Agnieszka Błaszczyk & Pofam Poznań \\
Beata Tietz & Amazonki Poznań \\
\hline Stowarzyszenie Amazonki im. św. Siostry & Faustyny w Obornikach \\
Alicja Woryma & UM, Fizjostrefa \\
Hubert Zglinicki & UM, Fizjostrefa \\
Maciej Kwiatkowski & UM, Fizjostrefa \\
Martyna Witucka & UM, Fizjostrefa \\
Sylwia Kusiak & UM, Fizjostrefa
\end{tabular}

\begin{tabular}{lc} 
& Sztab marketingowo-promocyjny \\
\hline Joanna Budzik & UAM \\
Julia Becherka & UAM \\
\hline
\end{tabular}

Mikołaj Rogula

Boost Biotech Polska

\begin{tabular}{ll} 
Anna Landowska & UMK \\
\hline Michalina Krakowiak & KNP, UAM \\
Mariola Majewska & KNP, UAM \\
\hline Oskar Kołacki & KNP, UAM
\end{tabular}




\section{Tutoring Gedanensis}

\author{
Legenda \\ KNP Koło Naukowe Przyrodników Uniwersytetu \\ im. Adama Mickiewicza w Poznaniu \\ UAM Uniwersytet im. Adama Mickiewicza w Poznaniu \\ USOM Uniwersyteckie Stowarzyszenie \\ Onkologii Multidyscyplinarnej \\ WCO Wielkopolskie Centrum Onkologii \\ UM Uniwersytet Medyczny \\ im. Karola Marcinkowskiego w Poznaniu \\ OPEN Ośrodek Profilaktyki i Epidemiologii \\ Nowotworów w Poznaniu \\ UMK Uniwersytet Mikołaja \\ Kopernika w Toruniu
}

\section{Literatura:}

Anastasiadi, Z., Lianos, G. D., Ignatiadou, E., Harissis, H. V., Mitsis, M. 2017. Breast cancer in young women: an overview. Updates in surgery, 69(3), 313-317. DOI: 10.1007/s13304-017-0424-1.

Dagogo-Jack, I., Shaw, A. T. 2018. Tumor heterogeneity and resistance to cancer therapies. Nature reviews. Clinical oncology, 15(2), 81-94. https://doi.org: 10.1038/nrclinonc.2017.166.

Knopik-Skrocka, A., Kręplewska, P., JarmołowskaJurczyszyn, D. 2017. Tumor blood vessels and vasculogenic mimicry - current knowledge and searching for new cellular/molecular targets of anti-angiogenic therapy. Medical Journal of Cell Biology Vol.5 Issue 1 https://doi.org/10.1515/acb2017-0005.

Krakowiak, M., Knopik-Skrocka, A. 2018. Komórki nowotworowe - mocny przeciwnik. Czy potrafimy stworzyć skuteczną terapię przeciw-nowotworową? Tutoring Gedanensis 3 (1), 6-15.

Modrzyński, T., Gwit, M., Knopik-Skrocka, A 2019a. Czy immunoterapia punktów kontrolnych jest przyszłością onkomedycyny? Rozważania tuto-ringowe. Tutoring Gedanensis 4(2), 12-16.

Modrzyński, T., Gwit, M., Knopik-Skrocka, A. 2019b. Check point inhibitors - a future of immunotherapy in oncomiedicine? Vth International Conference on Research and Education, April, Abstracts, p.76.
Prasetyanti, P. R., Medema, J. P. 2017. Intra-tumor heterogeneity from a cancer stem cell perspective. Molecular cancer, 16(1), 41. DOI : 10.1186/s12943-017-0600-4.

https://anchor.fm/skarbywdlon [Dostęp 9.04.2021]

https://gco.iarc.fr/today/home [Dostęp 9.04.2021]

http://onkologia.org.pl/wp-content/uploads/Nowotwory_2017.pdf [Dostęp 9.04.2021]

https://www.youtube.com/watch?v=dtmsACeLWPci [Dostęp 9.04.2021]

Notka o autorkach:

Katarzyna Morańska - studentka II roku studiów II stopnia, kierunek Biotechnology na Wydziale Biologii UAM, kierownik Sekcji, pomysłodawczyni, organizatorka i uczest-niczka projektów PIERWSI W DŁOŃ oraz "Skarby w dłoń", laureatka konkursu Parlamentu Samorządu Studentów UAM Kowadto 2.0, naukowo związana z modelem $3 D$ raka piersi oraz wirusem SARS-Cov-2.

Maria Gwit - studentka III roku studiów I stopnia, kierunek Biotechnologia na Wydziale Biologii UAM, uczestniczka programu tutoringowego dot. immunoterapii nowotworów pod kierunkiem dr A. Knopik-Skrockiej, Prof. UAM (rok akadem. 2018-19), członkini Sekcji, wspótorganizatorka i uczestniczka projektów "PIERwSI W DŁOŃN" oraz "Skarby w dtoń", aktualnie realizuje prace licencjacka na temat roli niekodujacych RNA w glejaku wielopostaciowym.

dr Agnieszka Knopik-Skrocka, prof. UAM nauczyciel akademicki na Wydziale Biologii UAM, akredytowany praktyk tutoringu, opiekun naukowy Sekcji, współorganizatorka i uczestniczka projektów "PIERWSI W DŁOŃ oraz "Skarby w dłoń". 